\title{
膵ラ氏島に $\beta_{2}$-microglobulin 由来のアミロイド沈着を認めた 糖尿病性腎不全の 1 剖検例
}

\author{
井上聖士吾妻真幸平林 俊明稲垣王子 \\ 森 頴太郎 藤 田 嘉一 後藤 武 男* 三木 章 三* \\ 兵庫医科大学人工透析部 高砂市民病院内科*
}

(平成 1 年 8 月 17 日受付，同 2 年 2 月 20 日受理)

key words : 膵ランゲルハンス島, アミロイド沈着, $\beta_{2}$-microglobulin, 糖尿病性腎不全

〈要旨〉

糖尿病性腎不全で 4 回の血液透析後に消化管出血で死亡，剖検により膵ラ氏島に $\beta_{2}-\mathrm{MG}$ 由来のアミロイド沈着を 認めた症例を報告する. 68 歳, 女性, 約 10 年前初めて糖尿病と診断され食事療法を行っていた. 約 2 年前よりインス リン療法開始, 蛋白尿出現。4 か月前より高窒素血症, 浮腫のため入院, 保存的治療を行っていたが高窒素血症増悪 のため血液透析を開始, 計 4 回の透析を行うも消化管出血で死亡. 剖検膵のラ氏島にアミロイド沈着がみられ, PAP 法による免疫組織化学検査でアミロイド蛋白は $\beta_{2}-M G$ を含むことが証明出来た。他の全身臓器にはアミロイド沈着 はみられなかった。長期透析症例の全身臟器のアミロイド沈着の報告はあるが, 短期の糖尿病性腎不全の膵ラ氏島に $\beta_{2}-M G$ 由来のアミロイド沈着がみられたのは稀で珍しく貴重な症例と考えられた。

An autopsy case of a diabetic chronic renal failure patient demonstrating amyloid deposition containing $\beta_{2}$-microglobulin in the islets of Langerhans

Seishi Inoue, M. D., Masayuki Azuma, M. D., Toshiaki Hirabayashi, M. D., Oshi Inagaki, M. D., Hidetaro Mori, M. D., Yoshikazu Fujita, M. D., Takeo Gotoh, M. D.*, Shozo Miki, M. D.*

Dialysis Unit, Hyogo College of Medicine ; Department of Internal Medicine, Takasago City Hospital*

We report an autopsy case of diabetic renal failure that demonstrated the deposition of amyloid containing $\beta_{2}$ -microglobulin $\left(\beta_{2}-M G\right)$ in the islets of Langerhans.

The patient was a 68 -year-old diabetic female who had received diet and insulin therapy for 10 years, and was hospitalized because of systemic edema and azotemia 4 months previously. She died of intestinal bleeding after 4 hemodialyses. Histopathological examination showed the deposition of amyloid in the islets of Langerhans. It was confirmed by immunohistochemical examination using the peroxidase-antiperoxidase (PAP) method that the amyloid deposits contained $\beta_{2}$-MG. There was no amyloid deposition in other organs.

There are several reports concerning the visceral involvement of dialysis amyloidosis, having been found after only four hemodialysis treatments. It was confirmed that the amyloid contained $\beta_{2}-\mathrm{MG}$ as a component of dialysis amyloidosis.

\section{緒言}

長期透析患者に手根管症候群 1 4) 破壊性脊椎関節 症 ${ }^{5)}$ などアミロイドーシスに起因する合併症 ${ }^{6,7)}$ が重要な 問題となってきている，そして，最近この透析患者にみ られるアミロイドーシスの前駆蛋白が, 腎不全で高濃度 に貯留する $\beta_{2}$-microglobulin $\left(\beta_{2}-\mathrm{MG}\right)$ であることも証

井上 聖士 兵庫医科大学人工透析部

于 663 西宮市武庫川町 1-1 (0798-45-6111)
明されている ${ }^{8,9)}$. 一方, 内分泌臟器に沈着するアミロイ

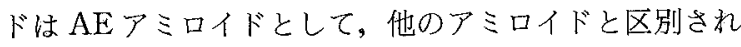
ている ${ }^{10)}$. 膵島アミロイドはインスリンまたはその前駆 物質から構成されていると考无られ，糖尿病はもとより， 非糖尿病にも認められている。今回我々は糖尿病性腎不 全のため血液透析を開始したが短期間で死亡し，剖検で 得られた膵に長期腎不全患者でしばしばみられる， $\beta_{2}$ -MG 由来のアミロイドが証明された症例を経験した。 
症例

68 歳, 女性。

現病歴：昭和 44 年頃糖尿病と診断, 食事療法を開始す る.昭和 50 年からインスリン療法を開始するもその頃よ り蛋白尿を認めるようになり，以後糖尿病性腎症による ネフローゼ症候群のため数回短期的入退院をくり返して いた。昭和 54 年に入り高窒素血症が持続，ネフローゼ症 候群も高度となったため入院，約 3 か月間は保存的治療 を行っていたが 4 か月目に入り，高窒素血症増悪のため 血液透析を開始した。しかし計 4 回の透析を行ったもの の消化管出血にて入院後 4 か月で死亡した。

家族歴：糖尿病なし，その他特別なものなし。

既往歴：特別なものなし。

現症：身長 $143.6 \mathrm{~cm}$ ，体重 $40.0 \mathrm{~kg}$ ，血圧 $230 / 84$ $\mathrm{mmHg}$, 脈拍 整 $84 /$ 分, 眼瞼結膜 貧血, 心 桩大および 機能性雑音, 肺 異常なし, 下肢 浮腫著明.

入院時検査成績 : 貧血, 高窒素血症, 代謝性アチドー シス，胸水と心囊液貯留を認めた。血中 $\beta_{2}-\mathrm{MG}$ は当時 測定されていなかった（表 1).

而糖能検查：経静脈性糖負荷試験（ivGTT）はブドウ 糖 $0.3 \mathrm{~g} / \mathrm{kg}$ の負荷を行い表 2 のごとき結果であったが IRI は殁ど反応せず K值は 0.59 で著しい耐糖能低下を 示した.

組織学的検査：剖検により得られた 9 種の臟器のすべ てに HE 染色とアミロイド沈着の有無を検索するため Congo Red 染色を行い, かつ偏光顕微鏡による複屈折性 を検查した。またアミロイド沈着が認められた脺につい ては抗七ト $\beta_{2}-\mathrm{MG}$ 抗体を用いた DAKO kit による peroxidase-antiperoxidase (PAP) 法でアミロイド蛋 白を同定した。

HE 染色では心，肺，肝，脾，甲状腺，副腎，胃壁に は特別な所見はみられなかった。㹂は殆どの系球体は硝 子化し，尿細管萎縮を認め糖尿病性腎症の末期像であっ た．膵はラ氏島に一致して無構造の沈着物がみられアミ ロイド沈着を思わせた，外分泌腺，間質には特記すべき 所見はみられなかった。

Congo Red 染色では膵ラ氏島は無構造な結節型ある いは塊状型の赤色の沈着物で置き換わり本来のラ氏島細 胞は著しく萎縮しかつ数が減少していた（図 1 太矢印). 同様の所見は膵組織内の他のラ氏島にも同様の沈着態度 で同程度に観察されアミロイド沈着と考えられた。ラ氏 島以外の組織では実質内小動脈壁に無構造な赤色の沈着 物（図 1 小矢印）がみられアミロイドの沈着が疑われた。 小葉間結合組織や被膜については明らかにアミロイド沈 着とする所見は得られなかった。

偏光顕微鏡による観察では図 2 に示すごとくラ氏島に
表 1 Laboratory data on admission

\begin{tabular}{|c|c|c|c|}
\hline 末梢血検査 & & 血液ガス & \\
\hline $\mathrm{RBC}$ & $223 \times 10^{4} / \mathrm{mm}^{3}$ & $\mathrm{pH}$ & 7.31 \\
\hline $\mathrm{Hb}$ & $6.5 \mathrm{~g} / \mathrm{d} l$ & $\mathrm{PO}_{2}$ & $83.2 \mathrm{mmHg}$ \\
\hline $\mathrm{Ht}$ & $20.9 \%$ & $\mathrm{PCO}_{2}$ & $31.5 \mathrm{mmHg}$ \\
\hline WBC & $4,500 / \mathrm{mm}^{3}$ & $\mathrm{HCO}_{3}$ & $15.7 \mathrm{mEq} / l$ \\
\hline Plt & $18.3 \times 10^{4} / \mathrm{mm}^{3}$ & $B E$ & $-9.1 \mathrm{mEq} / \mathrm{l}$ \\
\hline \multirow[t]{2}{*}{ 血沈 } & $55 / 1 \mathrm{hr}$ & & \\
\hline & & 尿検查 & \\
\hline 生化学検査 & & 尿量 & $1,000 \mathrm{~m} l$ \\
\hline BUN & $120 \mathrm{mg} / \mathrm{d} l$ & 糖 & 0 \\
\hline UAC & $9.2 \mathrm{mg} / \mathrm{d} l$ & 蛋白 & $100 \mathrm{mg} / \mathrm{d} l$ \\
\hline $\mathrm{Cr}$ & $8.0 \mathrm{mg} / \mathrm{d} l$ & ケトン体 & $(-)$ \\
\hline $\mathrm{Na}$ & $143 \mathrm{mEq} / l$ & 沈渣 & \\
\hline $\mathrm{K}$ & $4.3 \mathrm{mEq} / l$ & 赤血球 & $2 \sim 4 / F$ \\
\hline $\mathrm{Cl}$ & $94 \mathrm{mEq} / l$ & 白血球 & $3 \sim 5 / F$ \\
\hline GOT & $30 \mathrm{KU}$ & 徧平上皮 & $0 \sim 3 / \mathrm{F}$ \\
\hline GPT & $12 \mathrm{KU}$ & & \\
\hline ALP & $2.7 \mathrm{BLU}$ & その他 & \\
\hline $\mathrm{LDH}$ & $326 \mathrm{U}$ & 胸部 X-P & CTR $62 \%$ \\
\hline T-Chol & $241 \mathrm{mg} / \mathrm{d} l$ & & 両側胸水貯留 \\
\hline TG & $147 \mathrm{mg} / \mathrm{d} l$ & ECG & 左室肥大 \\
\hline $\mathrm{TP}$ & $6.4 \mathrm{~g} / \mathrm{d} l$ & & 左房負荷 \\
\hline Alb & $63.0 \%$ & & 低電位 \\
\hline$\alpha_{1}-\mathrm{G}$ & $3.4 \%$ & 心エコー & 心機能正常 \\
\hline$\alpha_{2}-\mathrm{G}$ & $7.5 \%$ & & 心囊液貯留 \\
\hline$\beta-\mathrm{G}$ & $6.1 \%$ & & \\
\hline$\gamma-\mathrm{G}$ & $20.0 \%$ & & \\
\hline
\end{tabular}

表 2 Blood sugar and IRI level at hospitalization

血糖日内変動 $(\mathrm{mg} / \mathrm{d} l)$

\begin{tabular}{ccccccc}
\hline $\begin{array}{c}\text { 空腹時 } \\
184\end{array}$ & $\begin{array}{c}\text { 朝食後 } \\
188\end{array}$ & $\begin{array}{c}\text { 昼食前 } \\
109\end{array}$ & $\begin{array}{c}\text { 昼食後 } \\
102\end{array}$ & $\begin{array}{c}\text { 夕食前 } \\
154\end{array}$ & $\begin{array}{c}\text { 夕食後 } \\
148\end{array}$ & $\begin{array}{c}\text { 年後10時 } \\
171\end{array}$ \\
\hline ivGTT & & & & & & \\
\hline Time $(\mathrm{min})$ & 0 & 5 & 10 & 20 & 30 & 60 \\
BS $(\mathrm{mg} / \mathrm{d} l)$ & 125 & 304 & 310 & 303 & 294 & 236 \\
$\mathrm{IRI}(\mu \mathrm{U} / \mathrm{m} l)$ & 49.4 & 47.8 & 45 & 48.4 & 56.4 & 61.9 \\
\hline
\end{tabular}

$\mathrm{K}$ 值 0.59

一致して淡緑から黄色に変わる複周折を示すアミロイド の沈着がみられた (図 2 太矢印)。同様の所見は実質内の 小動脈壁（図 2 細矢印）や被膜の結合織（同図短矢印） にも観察された。過マンガン酸カリウム処理によっても このアミロイドの染色性は消失せず， AA 蛋白ではない と考爷られた。

アミロイド蛋白が $\beta_{2}-\mathrm{MG}$ か否かを検索するため, PAP 法による免疫組織化学的染色を行った. 図 3 に示す ごとく, ラ氏島内沈着物に一致して赤褐色に $\beta_{2}-\mathrm{MG}$ が 染色された。ただ本法の場合は, Congo Red 染色の際に 


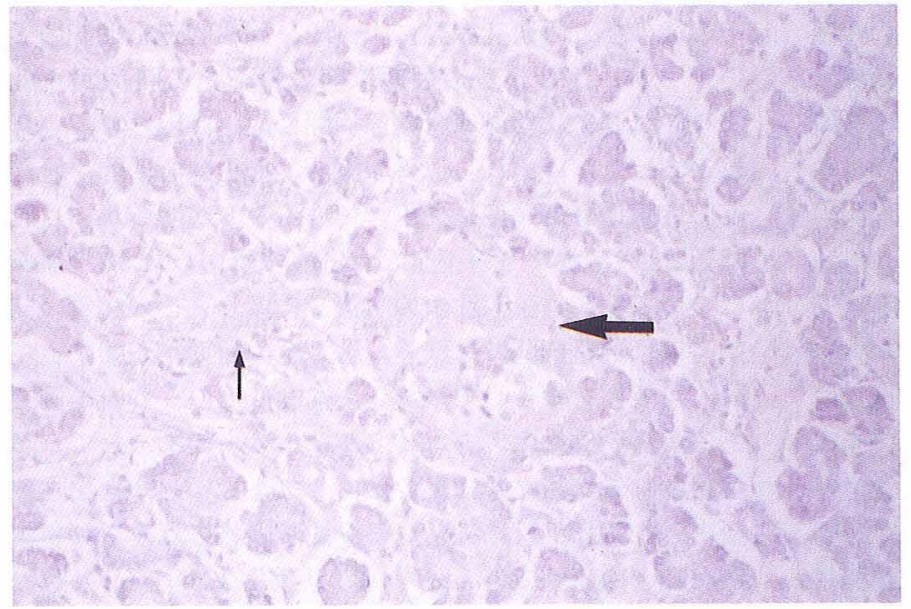

図 1 Amyloid deposit in islets of Langerhans $(\leftrightarrow)$ and small artery wall $(\leftarrow)$. Congo Red Stain. $\times 400$

図 2 Same pancreas as Fig.1 under polarized light. Islets $(\leftrightarrow)$ and a small artery $(\leftarrow)$ and capsules $(\leftarrow)$ are yellow and pale green. Congo Red Stain. $\times 200$

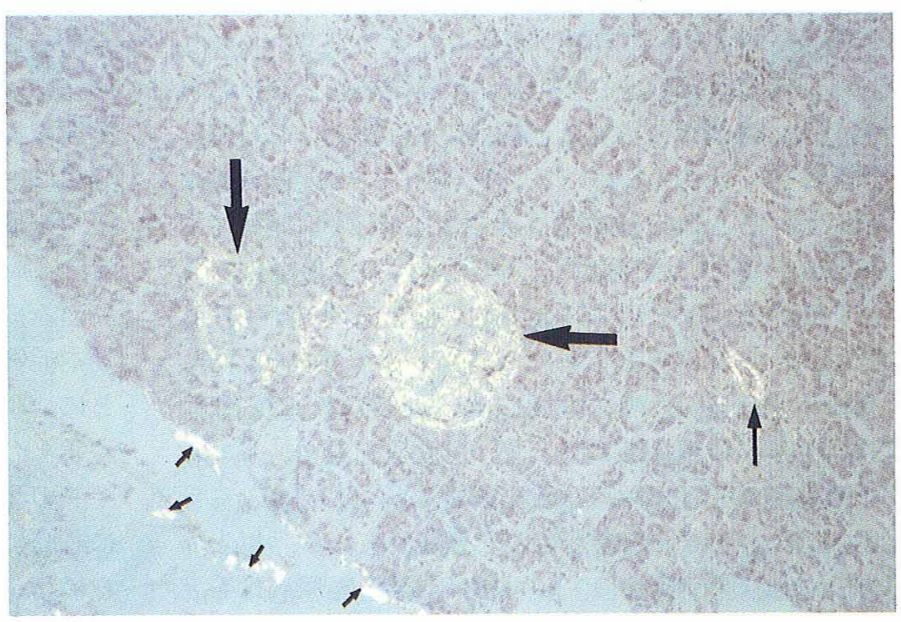

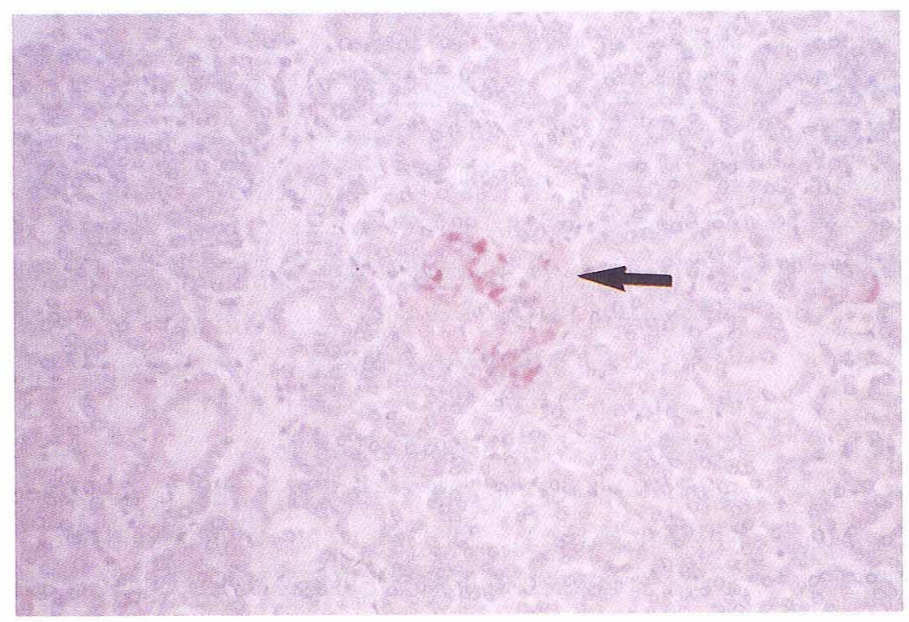

図 $3 \beta_{2}$-microglobulin $\left(\beta_{2}-\mathrm{MG}\right)$ in islets of Langerhans $(\diamond) \beta_{2}-\mathrm{MG}$ is reddish brown. Immunohistochemical stain by peroxidase-antiperoxidase(PAP) method (DAKO kit). $\times 400$ 
は同程度の濃度に一様に染色されたのに対し, 濃淡部分 が観察され, 濃染の部分は, 本来のラ氏島の細胞の残存 部に近い所に集まっている印象をうけた。この濃淡部分 については手根部靶帯にも同様にみられるため， $\beta_{2}-\mathrm{MG}$ 由来のアミロイドの沈着度の差と考えられた，他には小 動脈壁に軽度の染色性が認められたのみであった。

\section{考察}

内分泌臟器に沈着するアミロイドは第 3 回アミロイ ドーシス国際シンポジウム(1979)に㥂いて AE (amyloid of endocrine tissue related) アミロイドと呼ばれるよう

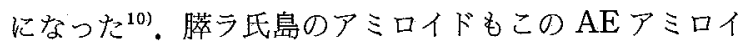
ドに属し，これは従来のアミロイドとは異なるインスリ ンまたはプロインスリンを前駆物質としている ${ }^{11,12}$.

糖尿病患者の膵ラ氏島に扔けるアミロイドの検出率は 種々の研究者によってかなり高率であることが判ってい る. Y $\operatorname{amada}^{13)}$ は 222 例の糖尿病の膵を検索しラ氏島に 55.8\% (124/222)にもアミロイド沈着を認めている.ま た年齢の高齢化と共に陽性率が高くなるとしている.し かし，ラ氏島のアミロイド沈着は非糖尿病にもみられ， Arey ${ }^{14)}$ は 50 歳以上の非糖尿病者の $16.7 \%(19 / 114) に$ ラ氏島にアミロイドを認めている。糖尿病と非梼尿病の 比較についてみると Bell ${ }^{15)}$ は糖尿病 1,661 例, 非糖尿病 3,959 例について比較検討し, 高齢者ほどラ氏島のアミ ロイド沈着の発生率が高く，かつ年齢を一致させてみる と糖尿病の方が $3 〜 18$ 倍頻度が高いと述べている. 同じ く Ehrlich ら ${ }^{16)}$ は糖尿病 $49.5 \%$ (45/91), 非糖尿病 $3.9 \%(7 / 178)$ にラ氏島にアミロイド沈着を認め, Haloy らは糖尿病 59\%(16/27), 非糖尿病 12\%（17/142）にラ 氏島にアミロイド沈着を認めたと報告している，以上の 報告のごとく膵ラ氏島のアミロイド沈着は糖尿病はもと より, 非糖尿病に招いてもしばしば認められている。

ラ氏島に沈着したアミロイドの性状については前述し たごとくインスリンまたはインスリン関連物質であるこ とが明らかにされている. Iwata ら ${ }^{17)}$ はインスリノーマ に合併したアミロイドから抽出したアミロイドで抗体を 作り PAP 法で糖尿病および老年者のラ氏島アミロイド を同定したところ同一であることを報告している。 Berns $ら^{11)}$, Shneider $ら^{12)}$ も蛍光抗体法にてラ氏島アミ ロイドにインスリンを証明している。すなわち糖尿病, 非糖尿病における膵ラ氏島アミロイドはインスリンであ ることがほほ確実になって来ている。

一方, 透析患者に手根管症候群 ${ }^{1 \sim 4)}$ や肩腕痛などアミロ イド沈着に由来すると考えられる症状が高頻度に発現し ており,透析アミロイドーシスと呼ばれるようになった。 このアミロイドは，腎不全に扔いて高值を示す $\beta_{2}-\mathrm{MG}$ がその前駆蛋白となっていることが下条ら ${ }^{8)}$ の研究から
明らかにされている.透析アミロイドーシスについては， その後の多くの研究者達によって, 比較的透析期間の短 いうちから，むしろ透析期以前の腎不全の時期から始 まっており，また従来骨関節周囲に症状が限られていた 感があったが, それら以外の臟器, 例えば心, 肺, 肝な どの内臟にも高頻度に発生していることが明らかにされ ている ${ }^{18,199}$. 我々も腎不全と合併症で死亡した 32 剖検例 についてアミロイド沈着の有無を検索し，その沈着の開 始時期は透析期間ではなく, 腎不全の時期から始まって いる可能性を報告して来た ${ }^{20)}$. 本例はそのうちの 1 例で

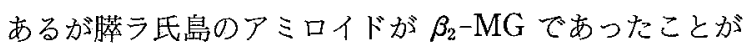
注目される。我々の知見では，これまで $\beta_{2}-\mathrm{MG}$ を主要 蛋白とする膵ラ氏島アミロイド沈着の報告はみられず本 例が唯一の症例である. 本例のラ氏島アミロイドが $\beta_{2}-$

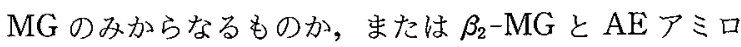
イドとの複合沈着であるか否かについては，抗インスリ ン抗体を用いた染色なども加えて検索をすすめていく考 えであるが, 図 1 のラ氏島のアミロイドの均一染色性と 図 3 の $\beta_{2}-\mathrm{MG}$ の濃淡を示した不均一染色性のギャップ を埋めるためにも AEアミロイドとの複合沈着の有無の 証明は大切な課題として残っている. ラ氏島以外の血管 壁や被膜のアミロイド沈着は $\beta_{2}-\mathrm{MG}$ 由来と考元てい

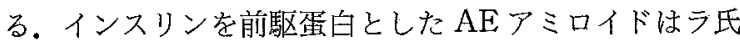
島のみに沈着するからである ${ }^{10)}$.

本症例が透析導入初期より，また膵のみに沈着したこ とについては補足的推定が必要であろう。前述したごと く我々の観察では透析導入初期に何らかの藏器にアミロ イドの沈着がみられるのは決して稀なことではなく，特 に心筋についてはかなり高頻度に観察されている20).さ らに $\beta_{2}-\mathrm{MG}$ は透析前から血中濃度が著しく上昇してい ることは衆知の事実であり, 本例は糖尿病性腎症由来て あり，当然透析前より高 $\beta_{2}-\mathrm{MG}$ 血症が存在し，アミロ イドの前駆蛋白として十分の濃度に達していたものと推 測される。

本例のアミロイド沈着が膵のみに特異的に生じたもの か，偶然膵のみに発見されたものなのか不明であるが, 脺のラ氏島以外の小血管壁にも沈着が認められているこ とは全身の臟器にも同様のアミロイド沈着が生じている 可能性はある.ただし今回の検索では発見出来なかった。 同様のことは心筋にもみられ，心筋のみに $\beta_{2}-\mathrm{MG}$ 由来 のアミロイド沈着がみられ他臓器にはみられない場合が 稀でない。ただラ氏島のアミロイド沈着については，本 例が糖尿病性腎症由来の腎不全であるので，まず $\mathrm{AE} ア$ ミロイド沈着が生じ, 腎不全の進行に従って $\beta_{2}-\mathrm{MG} の$ 血中濃度が上昇し, $\mathrm{AE}$ アミロイドが $\beta_{2}-\mathrm{MG}$ 由来のア ミロイド形成を中介促進した可能性は残されている，今 
後同様の症例が発見されればさらに深い考察が可能とな ろう。

\section{結語}

膵ラ氏島に $\beta_{2}-\mathrm{MG}$ 由来のアミロイド沈着を認めた糖 㽷病性腎不全の 1 剖検例を紹介した。

\section{文献}

1) Warren DJ, Otieno LS : Carpal tunnel syndrome in patients on intermittent haemodialysis. Postgrad Med J 51 : 450-452, 1975

2）竹本文美，野島美久，暮敬八郎，原 茂子，鈴木好 夫，二瓶 宏，三村信英，立花新太郎，内潟雅信： アミロイド沈着により手根管症候群を呈したと考え られる長期透析症例の一例。日腎誌 $25 ： 1449,1983$

3）下条文武，本間則行，丸山弘樹，西 慎一，荒川正 昭，小林宏人，斉藤英彦：透析アミロイド症. 腎と 透析 $23: 614-620,1987$

4）下条文武，本間則行，佐藤 隆，丸山雄一郎，大原 一彦，荒川正昭，斉藤英彦，石原法子 : 手根管症候 群とアミロイド．綜合臨床 36：384-391，1987

5）下条文武，本間則行，丸山弘樹，荒川正昭：透析ア ミロイド症と骨・関節症状。腎と骨代謝 $1: 155-165$, 1988

6）楊 鴻生，中野利彦，前田昌穂，別所康生，富永浩 司，立石博臣，中野謙吾，井上聖士：骨内アミロイ ド沈着により大腿骨頸部病的骨折をきたした一透析 症例。腎と骨代謝 $1 ： 107-114 ， 1988$

7）本間則行：透析アミロイドーシスに関する研究。血 液透析患者の手関節部囊胞状X線骨透亮像とアミロ イド骨関節症について. 透析会誌 $21: 389-398,1988$

8) Gejyo F, Odani S, Yamada T, Honma N, Saito H, Suzuki Y, Nakagawa Y, Kobayashi H, Maruyama $Y$, Hirasawa $Y$, Suzuki M, Arakawa $M: \beta_{2}$ -microglobulin: A new form of amyloid protein associated with chronic hemodialysis. Kidney Int $30: 385-390,1986$

9) Shirahama T, Skinner M, Cohen AS, Gejyo F, Arakawa M, Suzuki M, Hirasawa Y : Histochemical and immunohistochemical characterization of amyloid associated with chronic hemodialysis as $\beta_{2}$ microglobulin. Lab Invest 53 :
705-709, 1985

10）内野文彌，山下吉美，権藤俊一，岩田隆子：膵島〉 ミロイドーシス。臨床科学 $24: 166-174 ， 1988$

11) Berns AW, Owens CT, Blumenthal HT : A histo and immunopathologic study of the vessels and islets of Langerhans of the pancreas in diabetes mellitus. J Geront 19 : 179-189, 1964

12) Schneider HM, Störkel FS, Will W : The influence of insulin on local amyloidosis of the islets of Langerhans and insulinoma. Pathol Res Pract $170: 180-191,1980$

13) Yamada $Y:$ Pathologic study on amyloidosis. Amyloidosis of the islets of Langerhans in diabetes mellitus. Bull Yamaguchi Med School $15: 227-250,1968$

14) Arey JB: Nature of the hyaline changes in islands of Langerhans in diabetes mellitus. Arch Pathol 36 : 32-38, 1943

15) Bell ET : Hyalinization of the islets of Langerhans in nondiabetic individuals. Am J Pathol 35 : 801-805, 1959

16) Ehrlich JC, Ratner IM : Amyloidosis of the islets of Langerhans. A restudy of islet hyalin in diabetic and nondiabetic individuals. Am J Pathol 38 : 49-59, 1961

17) Iwata $T$, Uchino $F$ : Immunological homology of the amyloid of insulinoma and the islet amyloid of the aged. Biochemical characterization of the insulinoma amyloid. In "Amyloidosis", ed, Glenner GG p 813-820, Plenum Publishing Corporation, 1986

18) Nö̈L LH, Zingraff J, Bardin T, Kuntz C, Drüeke $\mathrm{T}$ : Tissue distribution of dialysis amyloidosis. Clin Nephrol 27 : 175-178, 1987

19) Campistol JM, Cases A, Torras A, Soler M, Munoz-Gomez J, Montliu J, Lopez-Pedret J, Revert L: Visceral involvement of dialysis amyloidosis. Am J Nephrol 7 : 390-393, 1987

20）井上聖士，吾妻真幸，平林俊明，稲垣王子，森穎太 郎, 藤田嘉一：長期透析患者に扔ける全身臟器のア ミロイド沈着の検討(抄録).日内会誌 $78: 231,1989$ 